\title{
FINALNA OBRÓBKA KRZEMIENNYCH SIEKIER I NARZECDZI SIEKIEROPODOBNYCH. STUDIUM EKSPERYMENTALNE ${ }^{1}$
}

\author{
FINAL PROCESSING OF FLINT AXES \\ AND WEDGE-SHAPED IMPLEMENTS. \\ AN EXPERIMENTAL STUDY
}

\author{
Radostaw L. Kubicki \\ Instytut Prahistorii. Uniwersytet im. A. Mickiewicza w Poznaniu \\ ul. Umultowska 89D, 61-614 Poznań, Polska \\ radoslawkubicki@onet.eu
}

\begin{abstract}
This article discusses the final processing of flint axes and wedge-shaped tools. The author in his considerations focuses primarily on the use of two hypothetical processes, i.e. hand grinding or grinding with extra weight at the final stage of manufacturing these tools. Thus, he refers to the work by Danish archaeologist B. Madsen of 1984, entitled "Flint Axe Manufacture in the Neolithic: Experiments with Grinding and Polishing of Thin-Butted Flint Axes", in which the researcher discussed, for the first time, an occurrence of these techniques in the axe-production process. The author of the article makes an attempt to repeat Madsen's achievements, to check validity of the concept, and to include also an issue of using so called abrasive materials to support a grinding process in prehistory.
\end{abstract}

KEY WORDS: flint axes, lithic technology, experimental archaeology, use-wear analysis.

\section{WPROWADZENIE}

Przez długi czas w środowisku naukowym temat siekier krzemiennych poruszany był jedynie w pracach poświęconych typologicznemu przyporządkowaniu tychże narzędzi. Prawie cała problematyka pozyskiwania tych artefaktów była w bardzo dużym stopniu niejako spychana na margines badawczy lub całkowicie pomijana. Jednym z pierwszych przykładów prac badawczych, które koncentrują się jedynie na

\footnotetext{
${ }^{1}$ Skrót pracy licencjackiej (Kubicki 2012) pt. „Finalna obróbka krzemiennych siekier i narzędzi siekieropodobnych. Studium eksperymentalne”, napisanej pod kierunkiem dr Katarzyny Pyżewicz.
} 
opisie danych przedmiotów, jest książka K.H. Brandta z 1967 r.: Studien über steinerne Äxte und Beile der Jüngeren Steinzeit und der Stein-Kupferzeit Nordwestdeutschlands, przedstawiająca częściowo w formie katalogu narzędzia krzemienne oraz kamienne, głównie siekiery, topory i młoty (tzw. kafary), schematy ich budowy, a także strefy występowania. Podobną pracą jest książka polskiego archeologa B. Balcera: Wytwórczość narzędzi krzemiennych w neolicie ziem polskich, wydana w $1983 \mathrm{r}$. Autor skupił się przede wszystkim na przedstawieniu różnego rodzaju narzędzi krzemiennych, także siekier oraz ich przynależności do różnych grup kulturowych. Głównym aspektem produkcji siekier krzemiennych do dziś najlepiej poznanym jest oczywiście aspekt technologiczny wstępnej wytwórczości. Dzięki zainteresowaniu tą dziedziną powstało kilka znaczących prac na ten temat. Jedną z nich jest opublikowany w Journal of Danish Archaeology w 1983 r. artykuł P.V. Hansena i B. Madsena pt. „Axe Manufacture in the Neolithic. An Experimental Investigation of a Flint Axe Manufacture Site at Hastrup Vænget, East Zealand". Jak sam tytuł wskazuje, badania prowadzone nad problematyką produkcji siekier krzemiennych miały charakter eksperymentalny i dotyczyły przede wszystkim technologii wytwórczości tych artefaktów. Bardzo dużą popularnością wśród naukowców cieszyły się także badania dotyczące oprawiania tych narzędzi w styliska oraz sposobu ich użytkowania. Na tym polu powstało kilka prac. Należy tu przede wszystkim wspomnieć o serii artykułów V. Rots, takich jak: „Towards an understanding of hafting: the macro- and microscopic evidences” (2003), „Hafting and raw materials from animals. Guide to the identification of hafting traces on stone tools" (2008a) czy "Hafting traces on flint tools" (2008b) oraz praca autorstwa D.S. Olausson pt. „Lithic technological analysis of the thin-butted flint axe” (1983). W $2003 \mathrm{r}$. R.W. Yerkes, R. Barkai, A. Gopher i O.B. Yosef w artykule „Microwear analysis of early Neolithic (PPNA) axes and bifacial tools from Netiv Hagdud in the Jordan Valley, Israel" opublikowali bardzo istotne badania traseologiczne ściśle związane $\mathrm{z}$ całym procesem użytkowania siekier krzemiennych. Odpowiedzi na różnego rodzaju pytania związane $\mathrm{z}$ wytwarzaniem omawianych $\mathrm{w}$ tej pracy narzędzi poszukuje się także w analogiach etnograficznych. Takim artykułem jest "Stone axes in ethnographic situations: some examples from New Guinea and the Solomon Islands" autorstwa P. Phillipsa (1979).

Temat niniejszej pracy zaistniał w literaturze przedmiotu stosunkowo niedawno. W 1996 r. W. Borkowski i W. Migal opublikowali pracę pt. „Ze studiów nad użytkowaniem siekier czworościennych z krzemienia pasiastego", w dużym stopniu poświęconą owemu zagadnieniu.

Największy wpływ na moje badania miała jednakże praca duńskiego archeologa: Bo Madsena. Została ona opublikowana w 1984 r. na łamach czasopisma Journal of Danish Archaeology pt. „Flint Axe Manufacture in the Neolithic: Experiments with Grinding and Polishing of Thin-Butted Flint Axes". Celem autora tej pracy było przedstawienie wyników przebadanych siekier krzemiennych $\mathrm{z}$ terytorium połu- 
dniowej Skandynawii, ze szczególnym uwzględnieniem takich cech tych siekier, które mogły mu pomóc $\mathrm{w}$ przeanalizowaniu procesu ostatniego stadia ich kształtowania. Głównym zadaniem jego badań było rozpoznanie śladów powstałych w czasie procesu szlifowania. Analizując neolityczne egzemplarze siekier krzemiennych, B. Madsen zauważył, że na powierzchniach wyszlifowanych narzędzi są głównie dwa rodzaje śladów charakteryzujących się określonymi cechami. Pierwszy z nich to ślady płytko zagłębiające się w powierzchnię krzemienia, biegnące w różnych kierunkach względem siebie i osi siekier. Co szczególnie ważne, narzędzia, na których można było zauważyć owe ślady, miały soczewkowatą formę ścian. Drugi rodzaj śladów zaobserwowanych przez badacza to ślady grube, głębokie, biegnące równolegle do osi narzędzia i względem siebie. Także forma całej siekiery ze wspomnianymi wyżej śladami była inna niż poprzednio. Tym razem wg B. Madsena ściany siekier były wypłaszczone.

W efekcie tych badań i odkryć B. Madsen wypracował hipotezę o istnieniu w pradziejach, przynajmniej na terenie południowej Skandynawii, dwóch diametralnie różnych sposobów szlifowania. Był to sposób ręczny i tzw. z dodatkową wagą, nazywany także szlifowaniem maszynowym.

Aby potwierdzić swoje przypuszczenia, autor omawianego artykułu przystąpił do prac eksperymentalnych. Pierwsze z nich dotyczyły szlifowania ręcznego. Efektem tych prac było uzyskanie soczewkowatej formy ścian wyszlifowanych siekier. Natomiast ślady po owej czynności przybrały formę stosunkowo płytkich i krótkich zarysowań, które, jak można było się spodziewać, układały się na powierzchni krzemienia w nieregularne formy. Był to efekt niemal identyczny z tym zaobserwowanym na neolitycznych artefaktach.

Drugi eksperyment był przeprowadzony przez Bo Madsena z użyciem tzw. maszyny utworzonej z drewnianego imadła - rozstrzępionej, drewnianej belki, w którą umieszczano szlifowane narzędzie. Nad imadłem znajdowało się sedno owego projektu, czyli dodatkowa waga, którą tworzył duży głaz. Szlifowanie za pomocą tego narzędzia musiało być wykonywane przez dwie osoby. Maszyna z zamontowaną $\mathrm{w}$ imadle siekierą była przesuwana na zasadzie moja-twoja po kamieniu szlifierskim, w tym przypadku po piaskowcu (ryc. 1). Za jej pomocą B. Madsen wykonał kilka prób swojego eksperymentu, których efekty były zaskakująco zbieżne z wynikami badań nad neolitycznymi siekierami. Ściany narzędzi tak wyszlifowanych przybrały wypłaszczoną formę. Natomiast interesujące badacza ślady okazały się tożsame z tymi zidentyfikowanymi na niektórych oryginałach. Były to długie, grube i głębokie zarysowania biegnące równolegle do siebie, jak również do osi narzędzia (Madsen, 1984).

Niestety B. Madsen po wyciągnięciu wniosków ze swojego projektu zaniechał dalszych prac nad tym zagadnieniem. Także inni badacze nie podjęli się wskrzeszenia tego projektu. 


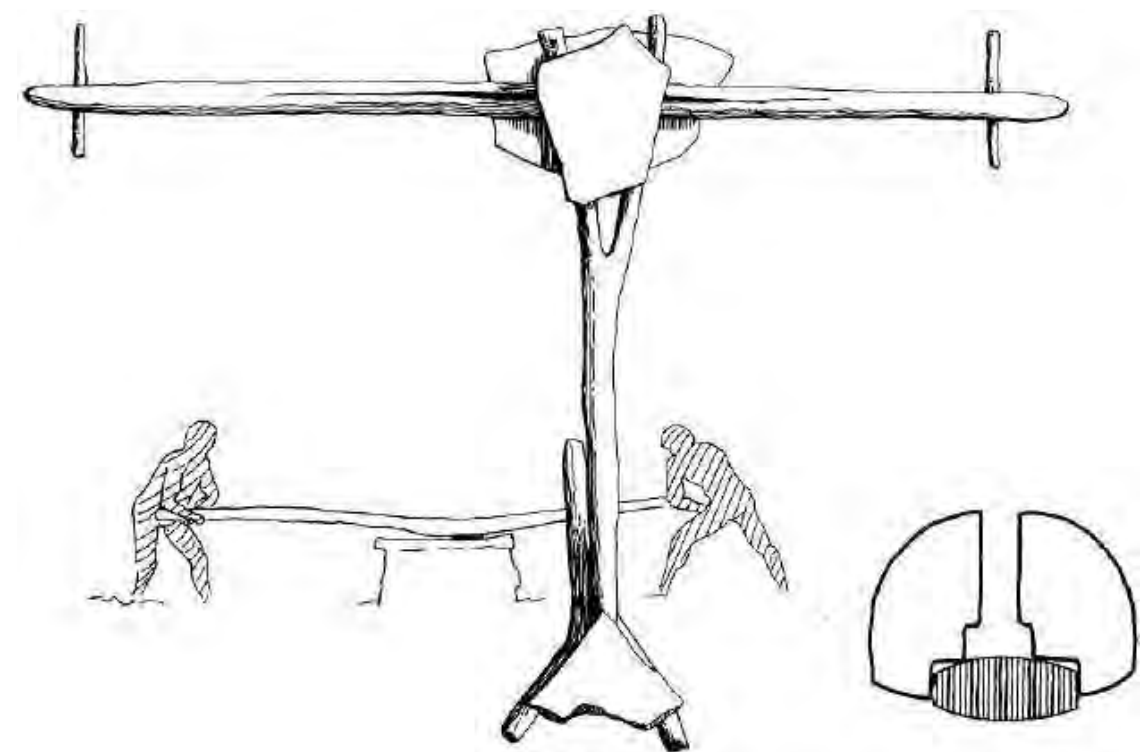

Ryc. 1. Model maszyny szlifującej (za: Madsen 1984)

Fig. 1. Model of a grinding system (after Madsen 1984)

\section{WSTĘP DO BADAŃ EKSPERYMENTALNYCH}

W 2011 r. w ramach pisania pracy licencjackiej postanowiłem zając się tym tematem. We wstępnych założeniach przyjąłem, że moja praca ma być pewnego rodzaju polemiką z wynikami prac B. Madsena - z uwzględnieniem nowych elementów, na które archeolog ten nie zwrócił wcześniej uwagi. Zainteresowała mnie przede wszystkim sprawa tzw. podsypek i możliwości zastosowania ich przez ludność pradziejową. Powstało pytanie: jaki wynik otrzymam po zastosowaniu podsypek z jednoczesnym powtórzeniem projektu B. Madsena?

\section{Matryca podsypek}

W mojej pracy podsypką nazywam piasek lub okruchy krzemienne pełniące funkcję materiału ściernego. Matryce stanowią wydzielone przeze mnie cztery rodzaje tychże podsypek. Trzy pierwsze to podsypki piaskowe, różniące się między sobą granulacją ziaren. Podsypka $\mathrm{nr} 1$ to ziarna o grubości zamykającej się w przedziale $0,5-1 \mathrm{~mm}$ (ryc. 2:A). Podsypka nr 2 to piasek z ziarnami o grubości większej lub równej $1 \mathrm{~mm}$, ale mniejszej niż $2 \mathrm{~mm}$ (ryc. 2:B). Ostatnia podsypka żwirowa to ziarna o grubości większej lub równej $2 \mathrm{~mm}$ (ryc. 2:C). W moich pracach eksperymentalnych odrzuciłem ziarna o grubości mniejszej niż $0,5 \mathrm{~mm}$. Z wcześniejszych 
doświadczeń związanych z pracami przygotowawczymi wiedziałem, że podsypka o takiej granulacji ma bardzo znikomy wpływ na proces szlifowania.

Ostatnia, czwarta podsypka, jest złożona głównie z łusek krzemiennych i pyłu, roboczo nazywana przeze mnie podsypką krzemienną (ryc. 2:D).

Matryca została stworzona przeze mnie w celu lepszego poznania oddziaływania granulacji ziaren piasku i pyłu krzemiennego na powierzchnię obrabianego narzędzia.

Ryc. 2. Matryca podsypek (fot. R.Ł. Kubicki)
A. Podsypka nr 1 (ziarna piasku $1>\varphi \geq 0,5 \mathrm{~mm}$ );
B. Podsypka nr 2 (ziarna piasku $2 \geq \varphi \geq 1 \mathrm{~mm}$ );
C. Podsypka nr 3 (ziarna piasku $\varphi \geq 2 \mathrm{~mm}$ );
D. Podsypka nr 4 (pył i łuski krzemienne)

Fig. 2. Matrix of abrasive materials (photo by R.Ł. Kubicki)
A. Abrasive material No. 1 (sand grains $1>\varphi \geq 0.5 \mathrm{~mm}$ );
B. Abrasive material No. 2 (sand grains $2 \geq \varphi \geq 1 \mathrm{~mm}$ );
C. Abrasive material No. 3 (sand grains $\varphi \geq 2 \mathrm{~mm}$ );
D. Abrasive material No. 4 (silt and flint chips)

A

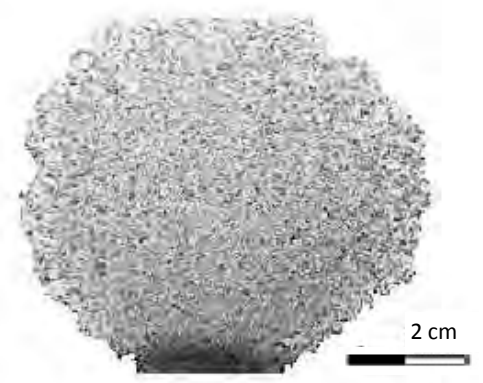

B

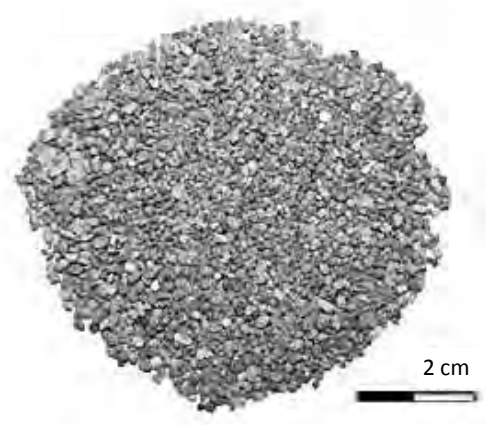

C

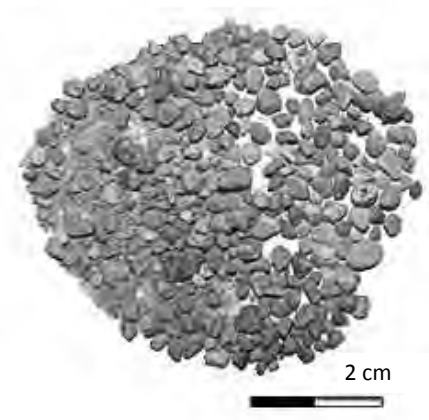

D

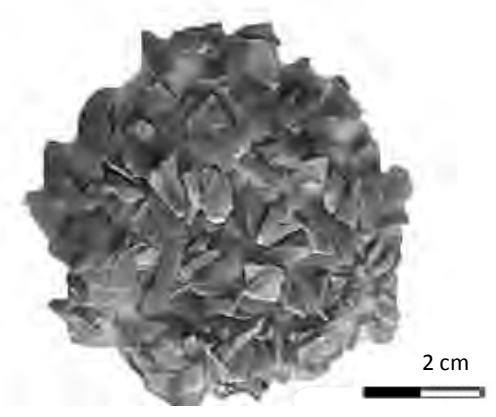




\section{Maszyna szlifująca}

Pierwsze próby skopiowania maszyny B. Madsena prowadzone były w $2010 \mathrm{r}$. podczas festynu na terenie rezerwatu archeologicznego w Biskupinie. Model ten, mimo że wzorowany był na projekcie tego badacza, ze względu na zastosowany materiał i błędy w konstrukcji nie sprawdzał się, przez co szybko został zastąpiony przez kolejne pomysły.

Po przeanalizowaniu konstrukcji przedstawionej przez Bo Madsena zadecydowałem o stworzeniu całkiem nowego projektu. Postanowiłem przede wszystkim radykalnie zmniejszyć liczbę elementów tej maszyny. Główną jej częścią stała się

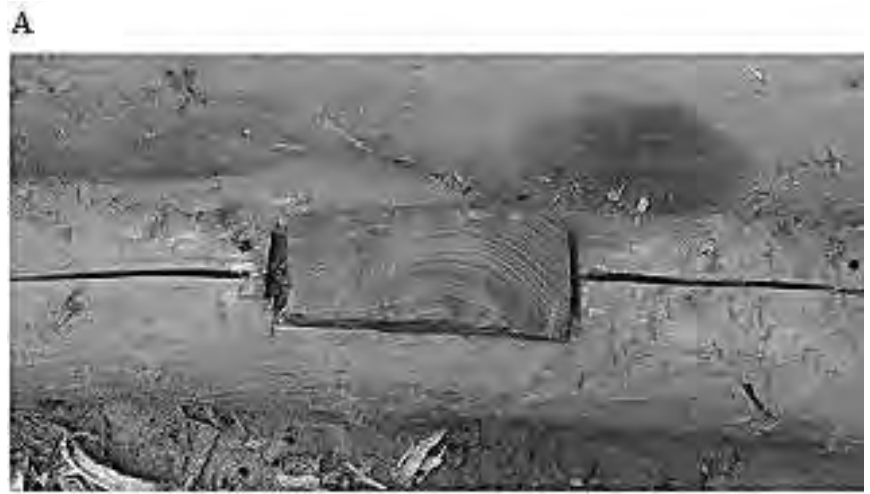

B

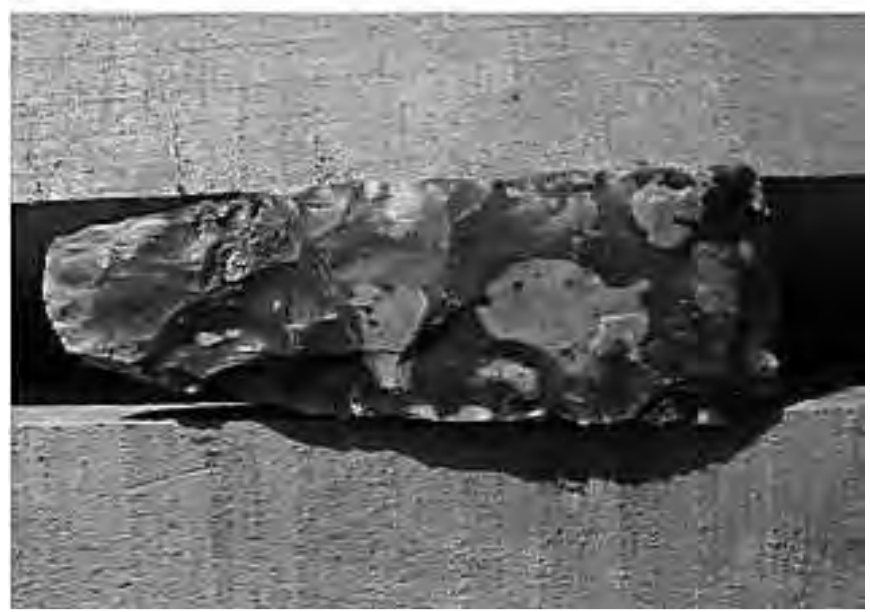

Ryc. 3. Maszyny szlifujące $\mathrm{z}$ umieszczonymi w imadłach eksperymentalnymi siekierami krzemiennymi A. Część środkowa maszyny nr 2 (fot. K. Pyżewicz); B. Część środkowa maszyny nr 3 (fot. A. Nowak)

Fig. 3. Grinding systems with experimental flint axes in vises

A. Middle part of system No. 2 (photo by K. Pyżewicz); B. Middle part of system No. 3 (photo by A. Nowak) 
jedna belka: długa na $2 \mathrm{~m}$, stosunkowo gruba, o średnicy ok. $20 \mathrm{~cm}$. Całkowicie zrezygnowałem z kamiennego obciążenia. Zastąpiłem je ciężarem samej maszyny i naciskiem wywieranym przez osoby szlifujące. Imadło natomiast zastąpiłem płytkim wyżłobieniem w owej kłodzie. Aby zamocować siekierę w konstrukcji maszyny, w środkowej części belki, poprzez wbijanie klinów, doprowadziłem do powstania rozczepienia ukierunkowanego równoległe do włókien drewna. Po umieszczeniu siekiery w wyżłobieniu konieczne było wyciągnięcie klinów tak, aby boki rozczepienia zacisnęły się na szlifowanym narzędziu. Model ten sprawdzał się wyjątkowo dobrze (ryc. 3:A).

Do przeprowadzenia moich badań eksperymentalnych wykorzystałem trzeci już model maszyny szlifującej. Skonstruowany został za pomocą współczesnych narzędzi i technik. Mimo to maszyna dokładnie naśladowała zasady działania poprzednich wersji. Złożona była $\mathrm{z}$ dwóch drewnianych prostopadłościanów o długości ok. $165 \mathrm{~cm}$, szerokości i wysokości $14 \mathrm{~cm}$. Po skręceniu ich ze sobą za pomocą dwóch długich śrub tworzyły one jedno wielkie imadło. Taka konstrukcja pozwalała na przeprowadzenie zaplanowanych przeze mnie badań (ryc. 3:B).

\section{Plan projektu}

Przed przystąpieniem do prac badawczych założyłem, że plan całego projektu powinien być prosty i jak najbardziej przejrzysty. Dlatego postanowiłem, że praca podzielona zostanie na dwa bloki powtarzające doświadczenie B. Madsena z 1984 r., rozszerzone o problem podsypek.

Pierwszy blok związany był z pracami obejmującymi szlifowanie maszynowe. Przeznaczyłem na ten cel dwie siekiery, które poddane zostały szlifowaniu z użyciem czterech wcześniej przedstawionych rodzajów podsypek - po jednej na każdą ścianę narzędzia.

Drugi blok mojej pracy miał powtarzać tę czynność z zastosowaniem techniki szlifowania ręcznego.

W obu przypadkach posłużyłem się siekierkami wykonanymi z krzemienia kredowego północno-zachodniego. Wybór tego surowca jest praktycznie przypadkowy i wynikał z jego dostępności.

\section{Płyta szlifierska}

Głównym celem mojego projektu była analiza śladów pozostawionych na siekierach przez podsypki. Podczas przeprowadzania eksperymentów istniało ryzyko, że użyta przeze mnie płyta szlifierska będzie zakłócać wyniki moich badań. Postanowiłem zatem zminimalizować to niebezpieczeństwo poprzez zastosowanie tylko jednego rodzaju piaskowca do wszystkich etapów moich prac. Ponadto chciałem spróbować określić charakter śladów pozostawianych przez tę skałę na powierzch- 
niach surowca krzemiennego. Jedynym sposobem, by to uczynić, było przeszlifowanie na czystym piaskowcu, tj. bez podsypek, przynajmniej jednej siekiery za pomocą zarówno techniki szlifowania ręcznego, jak i tzw. maszynowego.

\section{REALIZACJA BADAŃ EKSPERYMENTALNYCH}

Przystąpiłem do prac eksperymentalnych z przekonaniem, że ich wyniki będą przypominały te, które w toku swoich badań otrzymał B. Madsen. Zakładałem, że ślady szlifów będą odpowiednio różnić się od siebie ze względu na użytą podsypkę i że jednak będą zachowane podstawowe cechy wyznaczające technikę szlifowania. W praktyce miało to oznaczać, że użycie najgrubszej podsypki spowoduje największe spustoszenie w surowcu. Kolejne frakcje ziaren piasku miały natomiast działać coraz słabiej na powierzchnie siekier.

Jednakże w toku prac okazało się, że zdecydowana większość moich założeń opartych na przesłankach zawartych w pracy B. Madsena nie sprawdziła się. Niektóre wyniki moich badań były sprzeczne z rezultatami otrzymanymi przez Duńczyka, a inne rzuciły całkowicie nowe światło na omawianą problematykę.

\section{Blok I - Szlifowanie maszynowe}

Na początku moich prac eksperymentalnych przeprowadziłem doświadczenia z użyciem tzw. maszyny. Podczas tego etapu na powierzchniach siekier przetestowałem wszystkie wydzielone przeze mnie rodzaje podsypek, uzyskując $w$ ten sposób bardzo duży zbiór informacji. Ślady powstałe na tym etapie prac w dużej mierze odpowiadały moim oczekiwaniom oraz hipotezom przedstawionym przez B. Madsena (1984). Poza nielicznymi przypadkami większość z nich wykazywała cechy charakterystyczne dla śladów powstałych podczas tego rodzaju obróbki. Moje przypuszczenia związane ze stopniowym zmniejszaniem się wpływu podsypek na surowiec ze względu na ich wielkość jeszcze na tym etapie eksperymentów także zostały potwierdzone (ryc. 4).

Forma tak szlifowanych siekier, poza jednym wyjątkiem w tej części badań, także potwierdziła wnioski B. Madsena. Większość z boków narzędzi szlifowanych maszynowo uległa wypłaszczeniu.

\section{Szlifowanie na „czystej” płycie}

Podczas przygotowywania omawianego projektu uznałem za konieczne przetestowanie działania „czystej” płyty szlifierskiej. Dlatego też pomiędzy etapem szlifowania maszynowego a obróbką ręczną poddałem obróbce obiema technikami jedną z eksperymentalnych siekier, nie używając w tym procesie podsypek. 
A

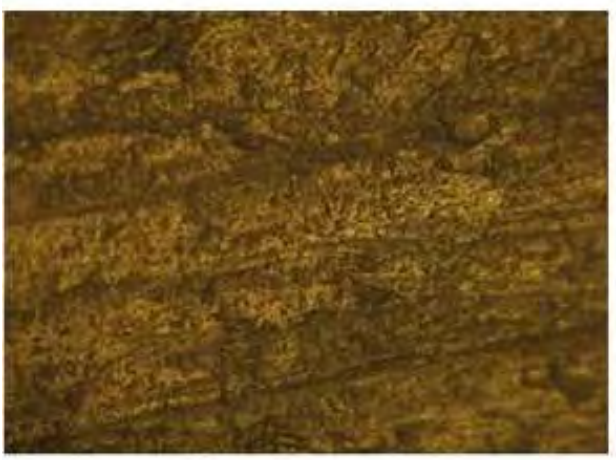

C.

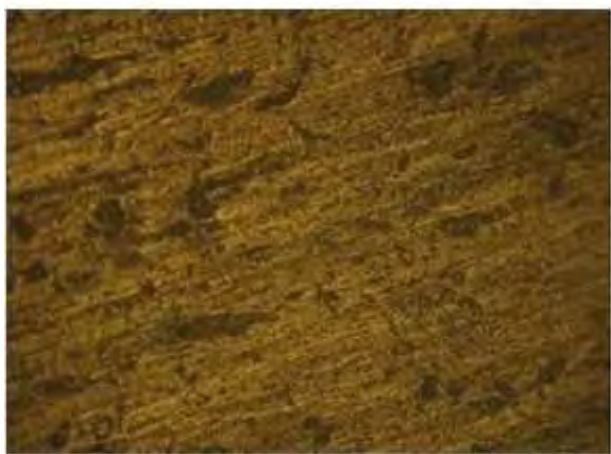

B

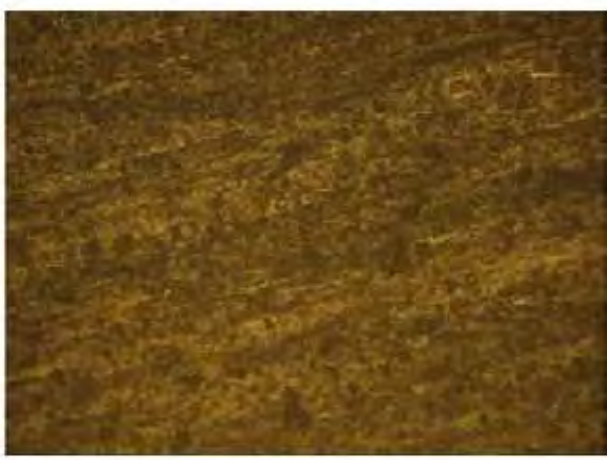

D

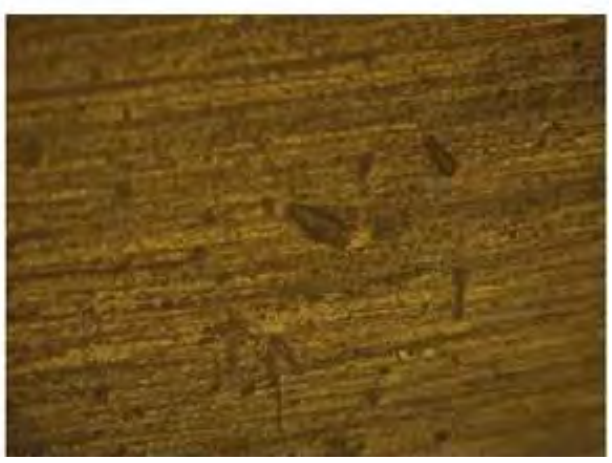

Ryc. 4. Ślady powstałe na krzemieniu tzw. rugijskim po zastosowaniu szlifowania maszynowego z użyciem czterech rodzajów podsypek

A. Podsypka nr 4; B. Podsypka nr 3; C. Podsypka nr 2; D. Podsypka nr 1

Fig. 4. Traces of mechanical grinding using four kinds of abrasive material on so-called Rugian flint A. Abrasive material No. 4; B. Abrasive material No. 3; C. Abrasive material No. 2; D. Abrasive material No. 1

Rezultatem tego dodatkowego etapu powinno być nie tylko określenie śladów pozostawionych przez płytę szlifierską, ale także uzyskanie wyników tożsamych z rezultatami badań przywoływanego przeze mnie duńskiego archeologa. Znaczy to tyle, że charakter owych powstałych w tej części badan śladów szlifowania powinien być analogiczny do charakteru śladów otrzymanych podczas prac badacza.

Jednak tak się nie stało. Okazało się, że efekty szlifowania ręcznego były znacznie bardziej wyraźne niż te otrzymane po obróbce maszynowej. Po tej pracy powstały zarysowania dużo grubsze i głębsze niż w drugim przypadku (ryc. 5).

Pomimo takich rezultatów obydwa szlifowane boki przybrały formę oczekiwaną z zastosowaniem tej techniki. Strona szlifowana maszynowo została wypłaszczona, natomiast ta obrabiana ręcznie - nie. 
A
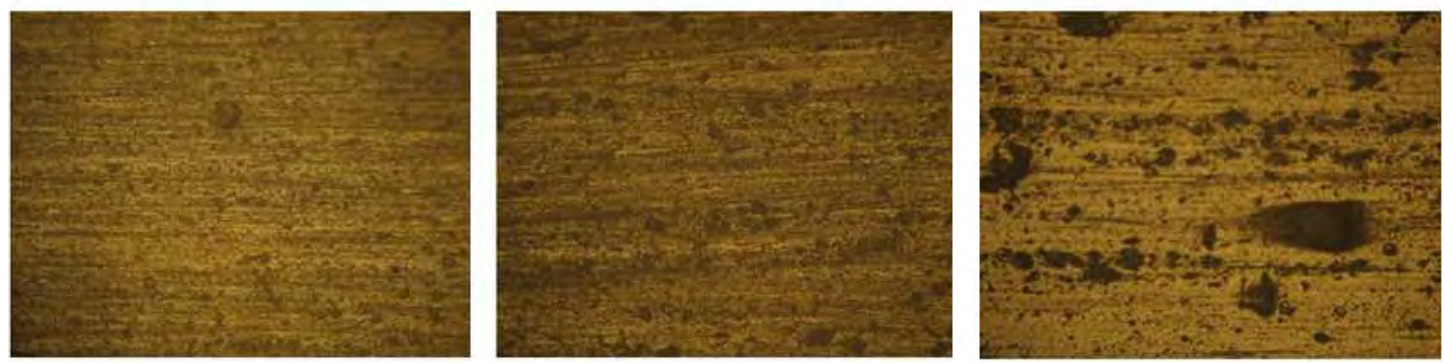

B
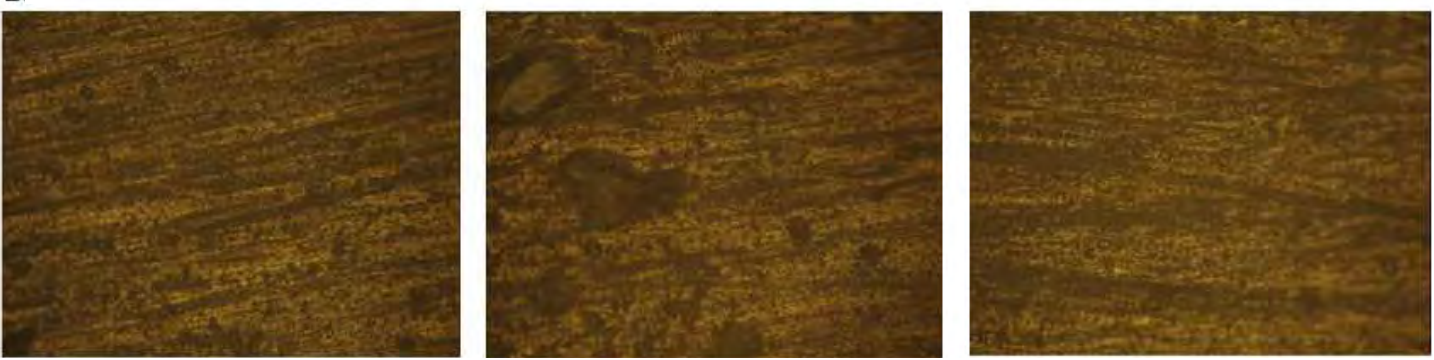

Ryc. 5. Ślady powstałe podczas szlifowania krzemienia tzw. rugijskiego bez użycia podsypek

A. Szlifowanie maszynowe; B. Szlifowanie ręczne

Fig. 5. Traces of grinding without an abrasive material on so-called Rugian flint

A. Mechanical grinding; B. Hand grinding

\section{Blok II - Szlifowanie ręczne}

Ostatni etap moich doświadczeń dotyczył prac związanych ze szlifowaniem ręcznym. W tym przypadku, analogicznie do pierwszej części eksperymentów, zastosowane zostały wszystkie rodzaje przedstawionych wcześniej podsypek.

Efektem tych prac były bardzo często ślady, których dostrzeżenie było niezwykle trudne. Porównując je $\mathrm{z}$ analogicznymi do nich przykładami z bloku pierwszego, można było dostrzec znaczne różnice. Zgodnie z teorią B. Madsena (1984) ślady szlifowania ręcznego były odpowiednio mniejsze od tych zaobserwowanych na siekierach obrobionych maszynowo. Ich ułożenie względem siebie i osi narzędzia oraz kształt obrobionej siekiery potwierdzały to, co przedstawił w swojej pracy przywoływany archeolog (ryc. 6). Oznacza to, że ślady te układały się na siebie, przecinając pod różnym kątem zarówno siebie nawzajem, jak i oś narzędzia przechodzącą od ostrza do obucha. W rezultacie powstały narzędzia o soczewkowatej formie.

Jednak nie brakuje w tym przypadku także wyjątków. Na części eksperymentalnych egzemplarzy powstały ślady o różnych wielkościach, często przypominające te, które uformowały się na narzędziach szlifowanych maszynowo z użyciem drob- 
A



C.

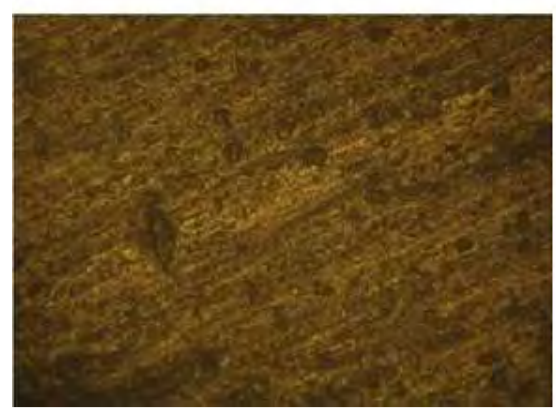

B.

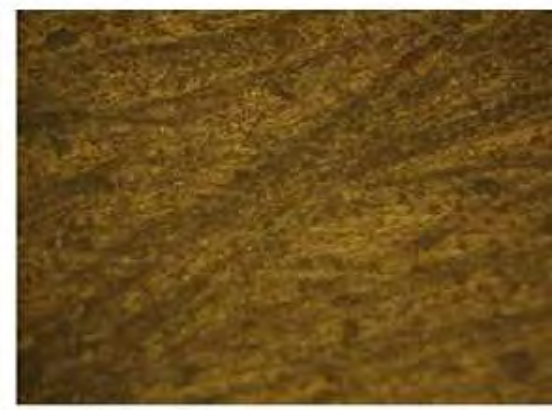

D.

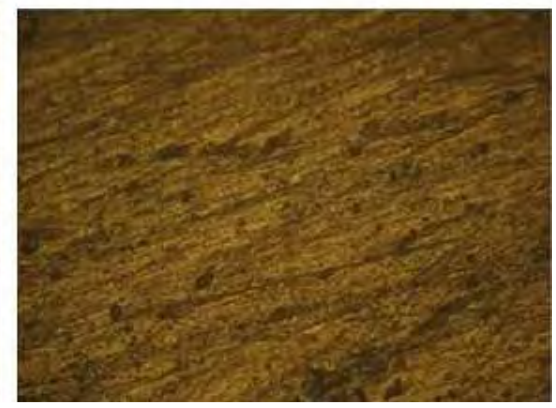

Ryc. 6. Ślady powstałe na krzemieniu tzw. rugijskim po zastosowaniu szlifowania ręcznego z użyciem czterech rodzajów podsypek

A. Podsypka nr 4; B. Podsypka nr 3; C. Podsypka nr 2; D. Podsypka nr 1

Fig. 6. Traces of hand grinding using four kinds of abrasive material on so-called Rugian flint A. Abrasive material No. 4; B. Abrasive material No. 3; C. Abrasive material No. 2; D. Abrasive material No. 1

nych podsypek. Ponadto podczas eksperymentu prowadzonego z użyciem podsypki $\mathrm{nr} 1$ pojawiły się trzy rodzaje śladów, które w znacznym stopniu skomplikowały moje badania oraz jakiekolwiek próby wyciągnięcia z nich klarownych wniosków. $\mathrm{Na}$ jednej płaszczyźnie powstały ślady o grubej strukturze, ślady odpowiednio od nich mniejsze oraz takie, które były bardzo trudno zauważalne, ale możliwe (ryc. 7). By wytłumaczyć ich zaistnienie w momencie, gdy tuż obok powstały duże, grube zarysowania, należy zaznaczyć, w jakim miejscu na płaszczyźnie surowca powstały. Jest bardzo prawdopodobne, że ślady tego typu nie pojawiłyby się, gdyby nie to, że znajdowały się one na powierzchni siekiery o jasnoszarej barwie. Była to część krzemienia, która uległa $\mathrm{w}$ innym stopniu krystalizacji niż reszta surowca, $\mathrm{z}$ którego pozyskano opisywane narzędzie. Nawet w skali makroskopowej można było dostrzec, że obie powierzchnie - ciemnoszara i jasnoszara - mają inną strukturę. Powstało w ten sposób przypuszczenie, że podlegały one obróbce w całkowicie inny sposób. 

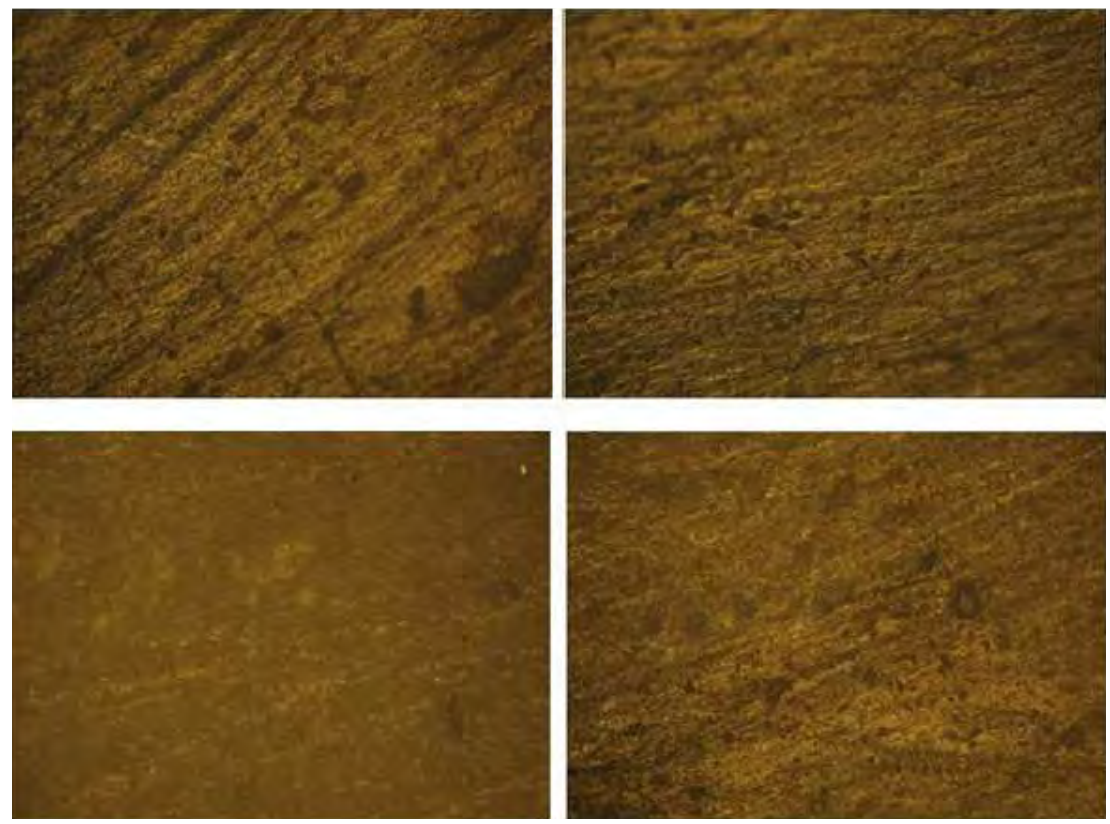

Ryc. 7. Różne rodzaje śladów powstałych pod wpływem oddziaływania podsypki nr 1 na krzemień tzw. rugijski podczas szlifowania ręcznego

Fig. 7. Various traces caused by using abrasive material No. 1 on so-called Rugian flint, during hand grinding

Obserwacja ta jest dla rozstrzygnięcia moich badań niezwykle istotna, gdyż niejako jest pretekstem do otwarcia nowego rozdziału mojej pracy. W sytuacji gdy na jednym egzemplarzu występowały dwa różne rodzaje śladów, których istnienie było spowodowane odmiennymi stopniami krystalizacji sąsiadujących ze sobą partii surowca, zasadne jest, aby zbadać, w jakim stopniu różne będą od siebie wyniki przeprowadzenia doświadczeń na kilku odmiennych gatunkach krzemienia.

\section{Blok III - Różne gatunki surowca}

Wyniki etapu moich badań związanych z użyciem podsypki nr 1 przy szlifowaniu ręcznym zmotywowały mnie do przeprowadzenia badań dodatkowych. Postanowiłem, że tym razem eksperymentom poddam różne gatunki krzemieni. Do zrealizowania tych celów wprowadziłem jednak kolejne zmiany w moich badaniach. Postanowiłem wykorzystać na tym etapie nie cztery, a dwa rodzaje podsypek - zwanych przeze mnie podczas prac podsypkami podstawowymi. Były nimi podsypka piaskowa nr 2 i krzemienna nr 4 (ryc. 2:B, D). 
Ze względu na to, że blok ten był blokiem dodatkowym i miał na celu jedynie sprawdzenie, w jaki sposób różne rodzaje krzemienia podlegają szlifowaniu i czy istnieje różnica pomiędzy wynikami tych prac na odmiennych surowcach, postanowiłem ograniczyć ten etap jedynie do eksperymentów związanych ze szlifowaniem maszynowym.

Wyniki prac prowadzonych nad tym zagadnieniem powinny być analogiczne do wyników uzyskanych w bloku pierwszym.

W tej części moich badań poddałem obróbce dwa nowe gatunki surowca. Były nimi krzemień ożarowski i pasiasty.

Pierwszy z nich zachowywał się podobnie jak krzemień rugijski, a powstałe na nim ślady były w znacznym stopniu zbieżne. Drugi zaś, poddany obróbce, wykazywał cechy mogące świadczyć o jego większej wytrzymałości, a tym samym mniejszej podatności na ścieranie. Porównując ślady powstałe na egzemplarzu z analogicznymi do niego przykładami z etapu pierwszego, łatwo można było zauważyć róż-

A.


B.
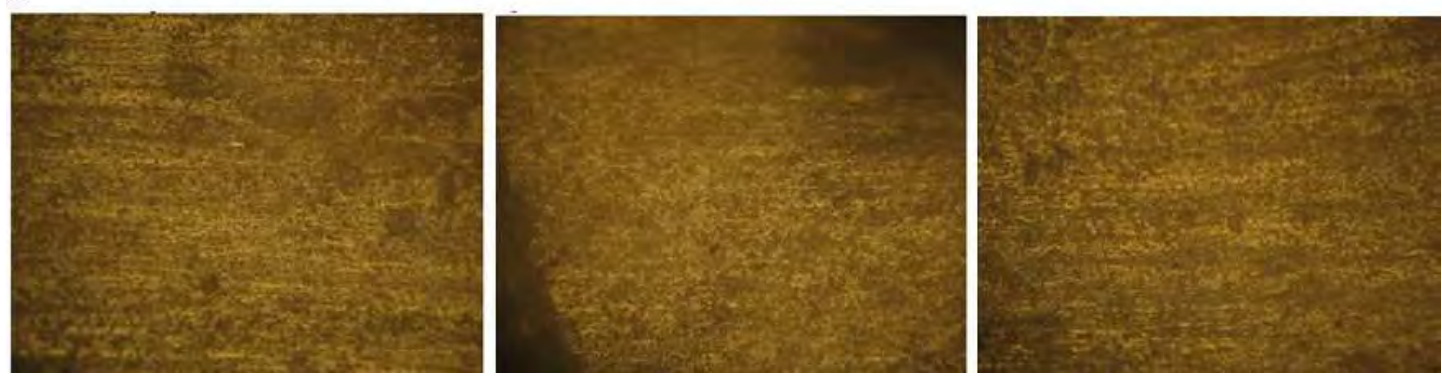

Ryc. 8. Ślady powstałe na krzemieniu pasiastym po zastosowaniu szlifowania maszynowego z użyciem podsypek $\mathrm{nr} 2 \mathrm{i} \mathrm{nr} 4$

A. Ślady po zastosowaniu podsypki $\mathrm{nr} 4$; B. Ślady po zastosowaniu podsypki $\mathrm{nr} 2$

Fig. 8. Traces of mechanical grinding with abrasive materials No. 2 and No. 4 on striped flint A. Traces of abrasive material No. 4 being used; B. Traces of abrasive material No. 2 being used 
nicę polegającą głównie na tym, że ślady powstałe na krzemieniu pasiastym były odpowiednio płytsze i mniejsze niż te widoczne na krzemieniu rugijskim (ryc. 8).

Także forma oszlifowanej siekiery potwierdzała te spostrzeżenia. Jeden z boków omawianego narzędzia nie został wypłaszczony.

\section{Podsumowanie eksperymentów}

Bo Madsen (1984) we wspomnianym artykule wypracowal bardzo konkretnie niezwykle interesujące tezy na temat ostatecznego kształtowania siekier krzemiennych. Przedstawił kilka zasad, dzięki którym można było się spodziewać, że interpretacja śladów produkcyjnych na siekierach będzie niezwykle prosta. W swojej pracy chciałem powtórzyć jego badania i uzyskać podobne rezultaty na płaszczyźnie własnych pomysłów. Jednakże po przeanalizowaniu wszystkich etapów moich eksperymentów doszedłem do wniosku, że jest to co najmniej trudne do wykonania.

Już na początkowych etapach prac zauważyłem pierwsze różnice pomiędzy wynikami naszych badań. Podczas zastosowania podsypki nr 2 przy szlifowaniu maszynowym pojawiły się dwie przecinające się wzajemnie płaszczyzny śladów, podczas gdy wg B. Madsena (1984) zarysowania na bokach obrabianych maszynowo powinny biegnąć równolegle do siebie i do osi narzędzia (tabela 1).

Kolejna różnica pojawiła się przy zastosowaniu podsypki nr 1. Mimo szlifowania maszynowego bok ten nie uległ wypłaszczeniu. Podobna sytuacja zaistniała później, przy obróbce krzemienia pasiastego przez podsypkę nr 4 (tabela 1).

Całkowitym zaskoczeniem były wyniki prac prowadzonych nad narzędziem szlifowanym na czystej płycie. Choć moim głównym celem podczas prowadzenia tego etapu eksperymentu było określenie cech śladów pozostawionych na krzemieniu przez płytę szlifierską, to w gruncie rzeczy było to dokładne powtórzenie eksperymentu B. Madsena. Mimo to uzyskaliśmy odmienne rezultaty. Na siekierze tak obrabianej większość śladów powstałych po szlifowaniu ręcznym była grubsza i szersza niż te, które ukazały się po pracy z użyciem maszyny (tabela 1).

Taka sytuacja w tym przypadku może podważać słuszność hipotez stawianych przez duńskiego archeologa.

W bloku drugim, przechodząc do etapu związanego z techniką szlifowania ręcznego, idąc za teorią B. Madsena, zakładałem, że otrzymam podobne rezultaty do tych zaobserwowanych na siekierach szlifowanych maszynowo - $\mathrm{z}$ tą różnicą, że ślady na nich będą odpowiednio płytsze, słabiej zarysowujące się na powierzchni krzemienia. Jednak także i ta hipoteza nie potwierdziła się. Ogromna różnorodność śladów na boku obrabianym z użyciem podsypki $\mathrm{nr} 1$ uświadomiła mi, że próby identyfikacji techniki szlifowania za ich pomocą są praktycznie skazane na niepowodzenie. Ponadto, jak 
to przedstawiłem w bloku dodatkowym, także rodzaj surowca ma wpływ na charakter śladów, jakie powstają na jego powierzchni, co jeszcze bardziej komplikuje badania (tabela 1).

\section{WNIOSKI}

Wyniki badań B. Madsena wydawały się niezwykle przejrzyste. Powstało wrażenie, że dzięki nim możliwe jest rozpoznanie użytych technik zastosowanych w celu kształtowania ostatecznego zabytków. Jednak wydaje się oczywiste, że ludność pradziejowa podczas obróbki szlifierskiej używała różnego rodzaju podsypek. Ta hipoteza wprowadza więc liczne zmiany w postrzeganiu rezultatów badań wspomnianego autora. Przedstawione przeze mnie wyniki prac eksperymentalnych mogą świadczyć o tym, że liczba kombinacji zdarzeń, jakie mogą nastąpić w czasie prac nad szlifowaniem narzędzi krzemiennych jest tak ogromna, że jest wręcz niemożliwe, by opierając się na analizie śladów produkcyjnych, móc z całą stanowczością określić, jaka technika została użyta przy obróbce owych przedmiotów. Przystępując do eksperymentów, oczekiwałem, że rezultaty moich badań będą jasne i klarowne. Zamiast tego, zgodnie z przysłowiem ,im dalej w las, tym więcej drzew", otrzymałem wiele różnorakich poszlak.

Bo Madsen (1984) swoją teorię na temat ostatecznego kształtowania siekier krzemiennych oparł na kilku konkretnych cechach. Były to:

- wygląd zewnętrzny narzędzia,

- ułożenie śladów na oszlifowanej płaszczyźnie,

- szczegółowe cechy morfologiczne wyżłobień.

Moje prace eksperymentalne wykazały jednak, że większość tych cech nie powinna być przez niego brana pod uwagę. Należy chociażby odrzucić bezkrytyczny pogląd mówiący o tym, że forma siekier szlifowanych maszynowo zawsze podlegała wypłaszczeniu.

Trzeba również zwrócić uwagę na cechy morfologiczne powstałych śladów, takie jak ich głębokość, szerokość czy długość. Tu także udowodniłem, że nie zawsze twierdzenia B. Madsena były słuszne.

Jedynym sposobem rozpoznawania użytej techniki szlifowania, który można brać pod uwagę, jest moim zdaniem analiza ułożenia głównych śladów powstałych podczas obróbki na płaszczyźnie narzędzia. To twierdzenie podyktowane jest tym, że praktycznie tylko do tych cech morfologicznych wyżłobień nie miałem w moich badaniach żadnych większych zastrzeżeń.

Poprzez moją pracę nad zagadnieniem ostatecznego kształtowania siekier krzemiennych i narzędzi siekieropodobnych chciałem, idąc za przykładem Bo Madsena, stworzyć podwaliny pod przyszłe metody badawcze pozwalające na poznanie tech- 
nik obróbki narzędzi poddanych szlifowaniu. Choć zadanie to okazało się nad wyraz trudne, ufny jestem, że wiedza, jaką zgromadziłem w niniejszej pracy, w znaczący sposób przysłuży się następnym badaniom archeologicznym.

\section{BIBLIOGRAFIA}

Balcer B.

1983 Wytwórczość narzędzi krzemiennych w neolicie ziem polskich. Wrocław: Ossolineum.

Borkowski W., Migal W.

1996 Ze studiów nad użytkowaniem siekier czworościennych w pradziejach. W: W. Brzeziński, W. Borkowski, W. Migal (red.), Studia nad gospodarka surowcami krzemiennymi w pradziejach (t. III, s. 141-165). Warszawa: Państwowe Muzeum Archeologiczne w Warszawie, Zespół do Badań Pradziejowego Górnictwa.

Brandt K.H.

1967 Studien über steinerne Äxte und Beile der Jüngeren Steinzeit und der Stein-Kupferzeit Nordwestdeutschlands. Hildesheim: Lax.

Hansen P. V., Madsen B.

1983 Flint Axe Manufacture in the Neolithic. An Experimental Investigation of a Flint Axe Manufacture Site at Hastrup Vænget, East Zealand. Journal of Danish Archaeology, 2, s. $43-59$.

Kubicki R.Ł.

2012 Finalna obróbka krzemiennych siekier i narzędzi siekieropodobnych. Studium eksperymentalne. [Praca licencjacka, Instytut Prahistorii UAM, Poznań].

Madsen B.

1984 Flint Axe Manufacture in the Neolithic: Experiments with Grinding and Polishing of Thin-Butted Flint Axes. Journal of Danish Archaeology, 3, s. 47-62.

Migal W., Sałaciński S.

1996 Eksperymentalne wytwarzanie siekier czworościennych z krzemienia pasiastego. W: W. Brzeziński, W. Borkowski, W. Migal (red.), Studia nad gospodarka surowcami krzemiennymi w pradziejach (t. III, s. 121-139). Warszawa: Państwowe Muzeum Archeolo-

Olausson D.S. giczne w Warszawie, Zespół do Badań Pradziejowego Górnictwa.

1983 Lithic Technological Analysis of the Thin-Butted Flint Axe. Acta Archaeologica, 53, s. $1-87$.

Phillips P.

1979 Stone axes in ethnographic situations: some examples from New Guinea and the Solomon Islands. W: T.H. McK. Clough, W.A. Cummins (red.), Stone axe studies (s. 108-112). London: Council for British Archaeology Research Report 23.

Rots V.

2003 Towards an understanding of hafting: the macro- and microscopic evidence. Antiquity, 77 , s. 805-815.

Rots V.

2008a Hafting and raw materials from animals. Guide to the identification of hafting traces on stone tools. Anthropozoologica, 43, s. 43-66. 
Rots V.

2008b Hafting traces on flint tools. W: L. Longo and N. Skakun (red.), Prehistoric Technology, 40 Years Later: Functional Studies and the Russian Legacy Proceedings of the International Congress Verona (Italy), 20-23 April 2005 (BAR International Series 1783, s. 75-84). Oxford: Archeopress.

\title{
FINAL PROCESSING OF FLINT AXES AND WEDGE-SHAPED IMPLEMENTS. AN EXPERIMENTAL STUDY
}

\begin{abstract}
S u m m a ry
The subject of this article is a study of the final processing of neolithic flint axes. The author, by polemic with the work by Danish archaeologist Bo Madsen, "Flint Axe Manufacture in the Neolithic: Experiments with Grinding and Polishing of Thin-Butted Flint Axes", tries to check the validity of Madsen's study, and extend discussed issues with the subject of so-called abrasive materials which could have been used in the process of grinding of the regarded tools in prehistory. Therefore, the main objective of this study has been to provide answers to several questions: What might have been the final stage of production of flint axes, i.e. their grinding, like? By what means it might have been done? What traces of this treatment are formed on a shaped surface? And: What was an effect of using various types of abrasive materials on the process? Special emphasis has been laid on using a special system in the process of axe-processing as suggested by Madsen in the article mentioned above, for grinding with extra weight. As a result of all the attempts, a relatively rich evidence has been collected, sufficient to develop numerous hypotheses concerning the subject. The experimental study carried out for this purpose enriched archaeological knowledge concerning the final processing of flint axes. Moreover, it provided the author with materials necessary for further, more extensive research.
\end{abstract}


ANEKS

Tabela 1

\begin{tabular}{|c|c|c|c|c|}
\hline & & OBRÓBKA RĘCZNA & \multirow{2}{*}{ OBRÓBKA MASZYNOWA } & \\
\hline & & Schemat Bo Madsena & & \\
\hline & MA & $\begin{array}{l}\text { Brak wypłaszczenie powierzchni narzędzia. } \\
\text { Słabo widoczne ubytki surowca. }\end{array}$ & Powierzchnia uległa spłaszczeniu. & \\
\hline $\begin{array}{l}\text { RODZAJ } \\
\text { PODSYPKI }\end{array}$ & MI & $\begin{array}{l}\text { Ślady płytkie, cienkie i krótkie, ułożone } \\
\text { nieregularnie, chaotycznie. Często przeci- } \\
\text { nają się nawzajem i nachodzą na siebie. } \\
\text { Skierowane są w różnych kierunkach. }\end{array}$ & $\begin{array}{l}\text { Ślady głębokie, grube i długie. Często } \\
\text { przechodzące przez znaczną część wyszli- } \\
\text { fowanej powierzchni. Ułożone są równole- } \\
\text { gle do siebie. Nie przecinają się ze sobą } \\
\text { nawzajem. Skierowane są w tym samym } \\
\text { kierunku, na osi ostrze/obuch. }\end{array}$ & \\
\hline \multirow[b]{2}{*}{1} & MA & Brak wypłaszczenia powierzchni. & Powierzchnia nie uległa spłaszczeniu. & \\
\hline & MI & $\begin{array}{l}\text { Trzy rodzaje śladów: } 1 \text {. Drobne zarysowania, } \\
\text { zbieżne z charakterystyką Bo Madsena. } \\
\text { 2. Zarysowania o znacznej głębokości } \\
\text { i szerokości. } \\
\text { 3. Bardzo drobne, trudno zauważalne ślady } \\
\text { obróbki. Ułożone nieregularnie, chaotycz- } \\
\text { nie. Często przecinają się nawzajem, na- } \\
\text { chodzą na siebie. Skierowane są w różnych } \\
\text { kierunkach. }\end{array}$ & $\begin{array}{l}\text { Szereg drobnych, płytkich zarysowań } \\
\text { w części przedniej i tylnej. W części środ- } \\
\text { kowej pojawiły się ślady związane z płytą } \\
\text { szlifierską. Ułożone równolegle do siebie. } \\
\text { Nie przecinają się ze sobą nawzajem. Skie- } \\
\text { rowane są w tym samym kierunku, na osi } \\
\text { ostrze/obuch. }\end{array}$ & \\
\hline \multirow{6}{*}{2} & MA & Brak wypłaszczenia powierzchni. & Powierzchnia uległa spłaszczeniu. & \\
\hline & MI & $\begin{array}{l}\text { Ślady o płytkiej formie, często wypłasz- } \\
\text { czone i wygładzone. Ułożone nieregular- } \\
\text { nie, chaotycznie. Często przecinają się } \\
\text { nawzajem, nachodzą na siebie. Skierowane } \\
\text { są w różnych kierunkach. }\end{array}$ & $\begin{array}{l}\text { Ślady znacznie płytsze i smuklejsze niż te } \\
\text { zaobserwowane na boku A siekiery nr } 1 . \\
\text { Część z nich była ułożona prawidłowo, } \\
\text { równolegle do siebie. Jednakże są też ślady } \\
\text { przecinające się nawzajem. }\end{array}$ & \\
\hline & MA & & Powierzchnia uległa spłaszczeniu. & \multirow[b]{2}{*}{$\begin{array}{l}\text { KRZEMIEŃ } \\
\text { PASIASTY }\end{array}$} \\
\hline & MI & & $\begin{array}{l}\text { Ślady w znacznym stopniu przypominające } \\
\text { te, które powstały po podsypce } 1 \text {. Ułożone } \\
\text { równolegle do siebie. Nie przecinają się ze } \\
\text { sobą nawzajem. Skierowane są w tym } \\
\text { samym kierunku, zazwyczaj na osi ostrze/ } \\
\text { obuch. }\end{array}$ & \\
\hline & MA & & Powierzchnia uległa spłaszczeniu. & \multirow[b]{2}{*}{$\begin{array}{l}\text { KRZEMIEŃ } \\
\text { OŻAROWSKI }\end{array}$} \\
\hline & MI & & $\begin{array}{l}\text { Ślady płytsze i smuklejsze niż te zaobser- } \\
\text { wowane na boku A siekiery nr 1.Ułożone } \\
\text { równolegle do siebie. Nie przecinają się ze } \\
\text { sobą nawzajem. Skierowane są w tym } \\
\text { samym kierunku, na osi ostrze/obuch. }\end{array}$ & \\
\hline \multirow{2}{*}{3} & MA & Brak wypłaszczenia powierzchni. & Powierzchnia uległa spłaszczeniu. & \\
\hline & MI & $\begin{array}{l}\text { Płytkie ubytki w powierzchni surowca. } \\
\text { Liczne różnego rodzaju wyżłobienia - od }\end{array}$ & $\begin{array}{l}\text { Ślady głębokie, grube i długie. Często } \\
\text { przechodzące przez znaczną część wyszli- }\end{array}$ & \\
\hline
\end{tabular}




\begin{tabular}{|c|c|c|c|c|}
\hline & & $\begin{array}{l}\text { głębokich i grubych do płytkich i cienkich. } \\
\text { Ułożone nieregularnie, chaotycznie. Często } \\
\text { przecinają się nawzajem, nachodzą na siebie. } \\
\text { Skierowane są w różnych kierunkach. }\end{array}$ & $\begin{array}{l}\text { fowanej powierzchni. Ułożone równolegle } \\
\text { do siebie. Nie przecinają się ze sobą na- } \\
\text { wzajem. Skierowane są w tym samym } \\
\text { kierunku, na osi ostrze/obuch. }\end{array}$ & \\
\hline \multirow{6}{*}{4} & MA & Brak wypłaszczenia powierzchni. & Powierzchnia uległa spłaszczeniu. & \\
\hline & MI & $\begin{array}{l}\text { Rozległe, szerokie nacięcia i wyżłobienia. } \\
\text { Ponadto wiele mniejszych nacięć leżących } \\
\text { blisko siebie, łączących się ze sobą. Ułożo- } \\
\text { ne nieregularnie, chaotycznie. Często prze- } \\
\text { cinają się nawzajem, nachodzą na siebie. } \\
\text { Skierowane są w różnych kierunkach. }\end{array}$ & $\begin{array}{l}\text { Ślady głębokie, grube i długie. Często } \\
\text { przechodzące przez znaczną część wyszli- } \\
\text { fowanej powierzchni. Widoczne zmiażdże- } \\
\text { nia i ubytki surowca. Ułożone równolegle } \\
\text { do siebie. Nie przecinają się ze sobą na- } \\
\text { wzajem. Skierowane są w tym samym } \\
\text { kierunku, na osi ostrze/obuch. }\end{array}$ & \\
\hline & MA & & Brak wypłaszczenia powierzchni narzędzia. & \multirow[b]{2}{*}{$\begin{array}{l}\text { KRZEMIEŃ } \\
\text { PASIASTY }\end{array}$} \\
\hline & MI & & $\begin{array}{l}\text { Ślady w znacznym stopniu przypominające } \\
\text { te, które powstały po podsypce } 3 \text { lub } 2 \text {. } \\
\text { Widoczne zmiażdżenia i ubytki surowca. } \\
\text { Ułożone równolegle do siebie. Nie przeci- } \\
\text { nają się ze sobą nawzajem. Skierowane są } \\
\text { w tym samym kierunku, na osi ostrze/ } \\
\text { obuch. }\end{array}$ & \\
\hline & MA & & $\begin{array}{l}\text { Powierzchnia uległa spłaszczeniu podczas } \\
\text { jej szlifowania. }\end{array}$ & \multirow[b]{2}{*}{$\begin{array}{l}\text { KRZEMIEŃ } \\
\text { OŻAROWSK }\end{array}$} \\
\hline & MI & & $\begin{array}{l}\text { Ślady głębokie, grube i długie. Często prze- } \\
\text { chodzące przez znaczną części wyszlifo- } \\
\text { wanej powierzchni. Widoczne zmiażdżenia } \\
\text { i ubytki surowca. Ułożone równolegle do } \\
\text { siebie. Nie przecinają się ze sobą nawza- } \\
\text { jem. Skierowane są w tym samym kierun- } \\
\text { ku, na osi ostrze/obuch. }\end{array}$ & \\
\hline \multirow[b]{2}{*}{$\begin{array}{c}\text { BRAK } \\
\text { PODSYPKI }\end{array}$} & MA & Brak wypłaszczenia powierzchni. & Powierzchnia uległa spłaszczeniu. & \\
\hline & MI & $\begin{array}{l}\text { Dwa rodzaje śladów: 1. Ślady ledwo za- } \\
\text { uważalne. } \\
\text { 2. Wyraźne, szerokie, głębokie wyżłobienia. } \\
\text { Ułożone nieregularnie, chaotycznie. Często } \\
\text { przecinają się nawzajem, nachodzą na } \\
\text { siebie. Skierowane są w różnych kierun- } \\
\text { kach. }\end{array}$ & $\begin{array}{l}\text { Bardzo zróżnicowane ślady. Zbliżone do } \\
\text { tych po użyciu podsypki } 1 \text { i } 2 \text {. Ułożone } \\
\text { równolegle do siebie. Nie przecinają się ze } \\
\text { sobą nawzajem. Skierowane są w tym } \\
\text { samym kierunku, na osi ostrze/obuch. }\end{array}$ & \\
\hline
\end{tabular}

Legenda: MA - ślady makroskopowe; MI - ślady mikroskopowe 